\title{
Long-term effects of advice to consume a high-protein, low-fat diet, rather than a conventional weight-loss diet, in obese adults with Type 2 diabetes: one-year follow-up of a randomised trial
}

\author{
G. D. Brinkworth ${ }^{1} \cdot$ M. Noakes ${ }^{1}$ B. Parker ${ }^{1} \cdot$ P. Foster ${ }^{1} \cdot$ P. M. Clifton ${ }^{1}$ \\ ${ }^{1}$ Commonwealth Scientific Industrial and Research Organisation (CSIRO), Health Sciences and Nutrition, Adelaide, \\ South Australia, Australia
}

\begin{abstract}
Aims/hypothesis. This study compared the long-term weight loss and health outcomes at 1-year follow-up, after a 12-week intensive intervention consisting of two low-fat, weight-loss diets, which differed in protein content.

Methods. We randomly assigned 66 obese patients (BMI: $27-40 \mathrm{~kg} / \mathrm{m}^{2}$ ) with Type 2 diabetes to either a low-protein (15\% protein, 55\% carbohydrate) or high-protein diet (30\% protein, $40 \%$ carbohydrate) for 8 weeks of energy restriction $(\sim 6.7 \mathrm{MJ} /$ day $)$ and 4 weeks of energy balance. Subjects were asked to maintain the same dietary pattern for a further 12 months of follow-up.

Results. The study was completed by 38 of the subjects, with equal dropouts in each group. At Week 64, weight reductions against baseline were $-2.2 \pm 1.1 \mathrm{~kg}$ (low protein) and $-3.7 \pm 1.0 \mathrm{~kg}$ (high protein), $p<0.01$, with no diet effect. Fat mass was not different from
\end{abstract}

baseline in either group. At Week 12, both diets reduced systolic and diastolic blood pressure by 6 and $3 \mathrm{~mm} \mathrm{Hg}$ respectively, but blood pressure increased more with weight regain during follow-up in the lowprotein group $(p \leq 0.04)$. At Week 64 , both diets significantly increased HDL cholesterol and lowered C-reactive protein concentrations. There was no difference in the urinary urea : creatinine ratio at baseline between the two groups, but this ratio increased at Week 12 (in the high-protein group only, $p<0.001$, diet effect), remaining stable during follow-up in both diets.

Conclusions/interpretation. A high-protein weightreduction diet may in the long term have a more favourable cardiovascular risk profile than a lowprotein diet with similar weight reduction in people with Type 2 diabetes.

Keywords Blood pressure - Glucose . High protein · Insulin · Lipids · Obesity
Received: 15 April 2004 / Accepted: 18 July 2004

Published online: 6 October 2004

C) Springer-Verlag 2004

P. M. Clifton (

Commonwealth Scientific Industrial

and Research Organisation (CSIRO),

Health Sciences and Nutrition, P.O. Box 10041 BC,

Adelaide SA 5000, South Australia, Australia

E-mail: peter.clifton@csiro.au

Tel.: +61-8-83038826, Fax: +61-8-83038899

Abbreviations: CRP, C-reactive protein - CVD, cardiovascular disease · HDL-C, HDL-cholesterol · HOMA, homeostatic model assessment $\cdot$ LBM, lean body mass $\cdot$ LDL-C, LDL-cholesterol

Conflict of Interest Statement. The authors have declared that there are no conflicts of interest regarding this work.

\section{Introduction}

The prevalence of Type 2 diabetes is increasing and has become a major public health problem [1]. It is a strong independent risk factor for cardiovascular disease (CVD) and the risk of mortality from CVD is two to four times higher in people with diabetes [2]. Although there is a strong genetic predisposition to the development of Type 2 diabetes, obesity is a significant contributor [3]. Since approximately $80 \%$ of patients with Type 2 diabetes are overweight or obese, achieving long-term weight management is essential to minimise diabetes-associated morbidity.

The dietary approach for weight loss and treating Type 2 diabetes recommended by the Diabetes and Nutrition Study Group of the European Association 
Table 1. Baseline characteristics

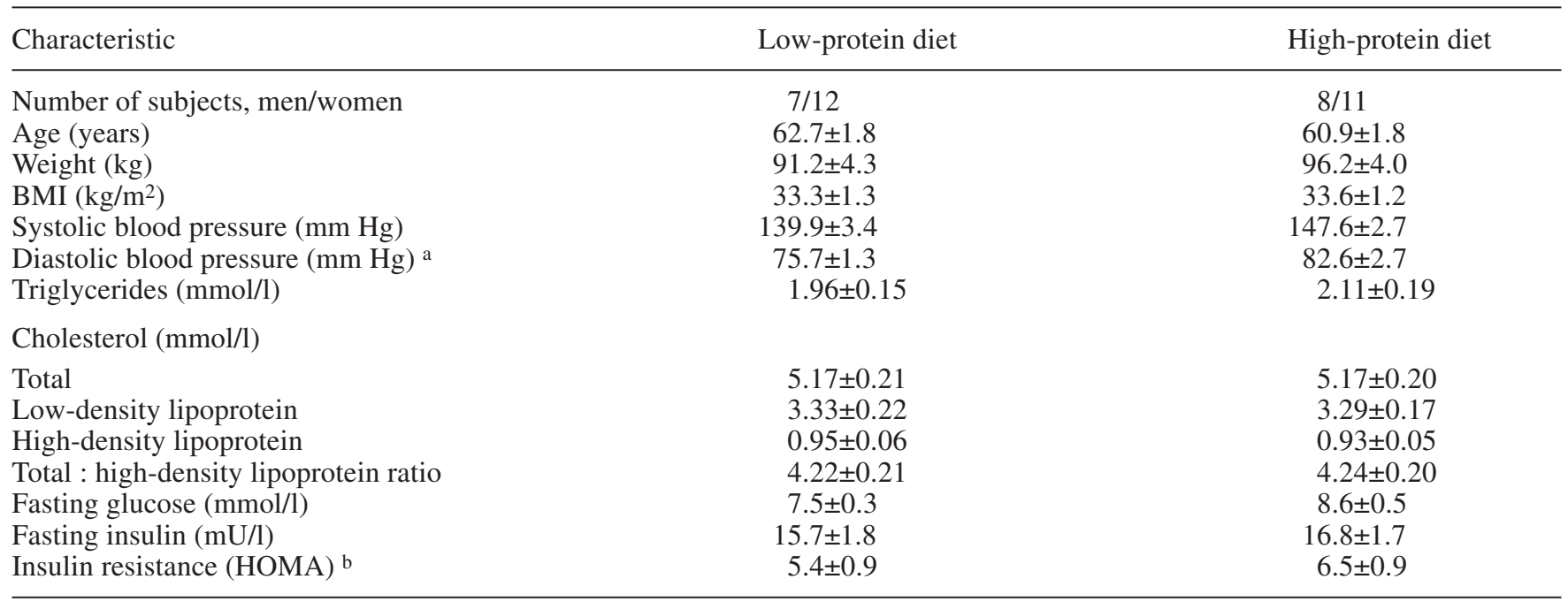

Values are means \pm SEM. a $p=0.003$ for difference between the two groups. ${ }^{\mathrm{b}}$ Insulin resistance was calculated according to the homeostatic model assessment (HOMA) [14]

for the Study of Diabetes is a high-carbohydrate, lowfat, energy-deficient diet [4]. However, long-term weight loss has been difficult to maintain using traditional dietary strategies, even with very low energy diets $[5,6]$. There has been considerable interest in alternative weight-loss strategies published in the lay press, but few have been tested in clinical trials. Further longer term studies evaluating the role of diet composition in weight loss, weight maintenance and improving CVD risk in Type 2 diabetes are required.

Several short-term, randomised, controlled studies ( $\leq 6$ months duration) have shown that the replacement of some dietary carbohydrate with protein in low-fat diets $(\leq 30 \%)$ enhances weight loss [7], is associated with favourable changes in body composition [7, 8, 9] and exerts beneficial effects on CVD risk factors, including insulin sensitivity [8], glycaemic control [10, 11] and lipid profile $[8,9,12]$. While these diets may offer modest short-term metabolic advantages, to date, there are no long-term clinical trials of their long-term efficacy, safety and acceptability compared to conventional low-fat, high-carbohydrate diets in persons with Type 2 diabetes. The purpose of the present study therefore, was to evaluate both compliance with, and the long-term metabolic effects of two low-fat diets with different protein : carbohydrate ratios on weight loss, body composition and CVD risk factors in obese subjects with Type 2 diabetes. This study compared the changes observed during a 1-year follow-up of participants in a previously published study that reported the short-term effects of these diets over 12 weeks [9].

\section{Subjects and methods}

Subjects. We recruited via public advertisement 66 overweight or obese adult subjects (BMI: $27-40 \mathrm{~kg} / \mathrm{m}^{2}$ ) with Type 2 diabe- tes. All subjects completed a health-screening questionnaire and potential subjects were excluded if they had proteinuria or a history of liver, unstable cardiovascular, respiratory, or gastrointestinal disease or a malignancy. The protocol and the potential risks and benefits of the study were fully explained to each subject before they provided written informed consent. All experimental procedures were approved by the Human Ethics Committee of the CSIRO (Commonwealth Scientific and Industrial Research Organisation).

A total of 38 subjects ( 7 men and 12 women on the low-protein diet, 8 men and 11 women on the high-protein diet) completed the entire 64-week study protocol (Table 1). Two subjects withdrew before commencement, and a further 26 subjects (lowprotein diet: 12; high-protein diet: 14) dropped out during the course of the study and were lost to follow-up (Fig. 1) (data for these subjects were not included in the final analysis). Of the 38 subjects who completed the study, 18 were taking antihypertensive medication, 17 required oral hypoglycaemic medications, 16 used lipid-lowering drugs and 3 required insulin. Most subjects had a sedentary lifestyle prior to study commencement, and no specific guidelines regarding physical activity were provided.

Experimental protocol. During the screening period, subjects were randomly assigned to the consumption of either a lowprotein or high-protein diet, using a random number generator after being matched pairwise for sex, BMI and fasting plasma glucose. The 64-week outpatient study consisted of three periods; an 8-week energy restriction period ( $\sim 6700 \mathrm{~kJ} /$ day or $30 \%$ caloric restriction) followed by a 4-week period in energy balance with the same macronutrient composition. At the end of these 12 weeks, all clinical outcomes were reassessed. The data from these periods have been previously reported [9].

After this initial 12-week intervention period, subjects were asked to maintain a similar dietary pattern as best they could for the succeeding 52 weeks and clinical outcomes were measured at the end of this period. During this period, contact between subjects and professional diet counsellors was minimal, so as to replicate the approaches used by most dieters. Every effort was made to encourage subjects to remain in the study and attend follow-up clinic visits at 3-monthly intervals for body weight assessment. The present report will focus on weight loss and metabolic changes during the follow-up period. 


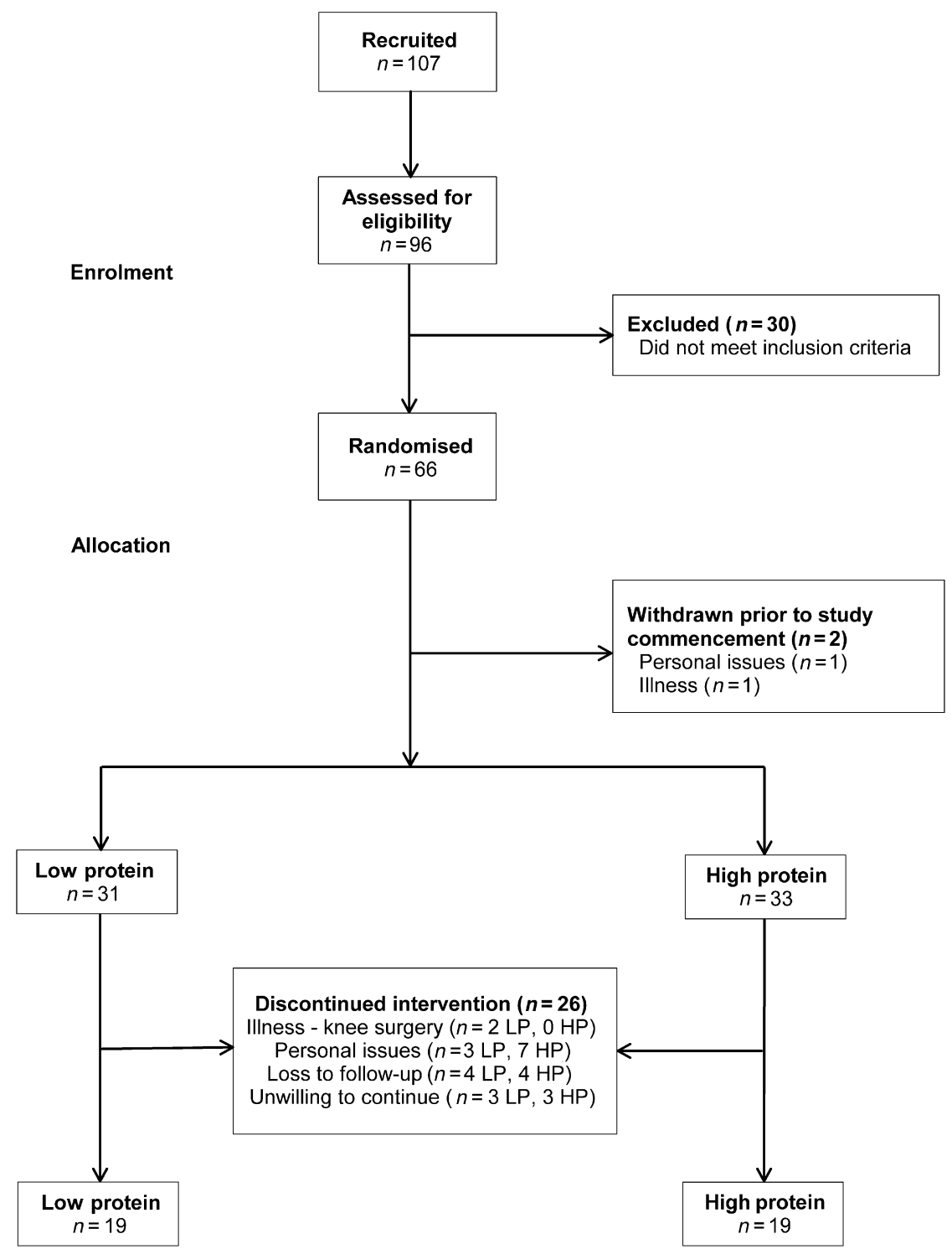

Fig. 1. Study parallel design flow chart. LP, low-protein diet; $\mathrm{HP}$, high-protein diet

At Weeks 0, 12 and 64 body composition was assessed using a whole-body dual X-ray absorptiometry scan. On two consecutive days at Weeks 0 and 12 and on a single day at Week 64, subjects attended the CSIRO clinic, having fasted overnight. During this visit, body mass, height and resting blood pressure were measured, after which a venous blood sample was drawn to determine blood lipids, glucose, insulin, $\mathrm{HbA}_{1} \mathrm{c}$ and C-reactive protein (CRP) concentrations. Subjects also attended the clinic at Weeks 25, 38 and 51 for a body weight assessment. At baseline and Week 12, a 24-hour urine save was collected on an outpatient basis. Thereafter a fasting morning urine sample was collected at each 3-monthly followup visit to the clinic (i.e. at Weeks 25, 38, 51 and 64). Urine samples were used to assess albumin concentrations and the urea : creatinine ratio with a view to measuring dietary compliance. All testing was conducted at the same time of day to avoid circadian effects.

Dietary intervention. Before the study began, subjects in both groups met a dietician, this meeting being repeated every two weeks up to Week 12. During the 8-week energy restriction period, the prescribed high-protein diet consisted of $30 \%$ of energy from protein, $40 \%$ from carbohydrate and $30 \%$ from fat; the low-protein diet consisted of $15 \%$ of energy from protein, $55 \%$ from carbohydrate and $30 \%$ from fat. Both diets were matched for fatty acid profile ( $8 \%$ saturated fatty acids, $12 \%$ mono-unsaturated fatty acids, $5 \%$ polyunsaturated fatty acids) and dietary fibre intake ( $30 \mathrm{~g} /$ day). During the subsequent 4 -week energy balance period, caloric intake was increased by $30 \%$, with a further $7 \mathrm{~g}$ protein in the low-protein diet and $21 \mathrm{~g}$ in the high-protein diet. The diets were prescriptive fixed menu plans and to assist with dietary compliance, subjects were supplied with key foods, which amounted to $60 \%$ of energy intake. Further details and differences between the two diets during these periods have been previously described [9]. For the next 12 months, subjects were asked to continue the same dietary pattern followed during the short-term study, but were not provided with any foodstuffs or professional dietary counselling.

Height, body weight and body composition. Height was measured to the nearest $0.1 \mathrm{~cm}$ using a stadiometer (SECA, Hamburg, Germany) with subjects barefoot in the free-standing position. Body weight was measured to the nearest $0.05 \mathrm{~kg}$ with 
subjects wearing light clothing and no shoes, using electronic digital scales (AMZ 14; Mercury, Tokyo, Japan). Body composition was measured by whole-body dual X-ray absorptiometry (Norland densitometer XR36; Norland Medical Systems, Fort Atkinson, Wis., USA) with a coefficient of variation of $2.3 \pm$ $0.9 \%$ for total fat mass and $2.1 \pm 0.4 \%$ for total lean mass.

Blood pressure. Resting blood pressure was measured in triplicate by automated oscillometry (HDI/Pulsewave CR-2000; Eagan, Minn., USA), with subjects in a seated position.

Biochemical analyses. Fasting blood samples were collected in tubes containing no additives for lipids, insulin and CRP, sodium fluoride/EDTA for glucose and EDTA for $\mathrm{HbA}_{1} \mathrm{c}$ measurements. Plasma or serum was isolated by centrifugation at $2000 \mathrm{~g}$ for 10 minutes at $5{ }^{\circ} \mathrm{C}$ (Beckman GS-6R centrifuge; Beckman Instruments, Palo Alto, Calif., USA) and frozen at $-20{ }^{\circ} \mathrm{C}$. Urine samples to assess dietary compliance and albumin excretion were frozen at $-80{ }^{\circ} \mathrm{C}$ in polyethylene tubes. Biochemical assays were performed in a single assay at completion of the study, except $\mathrm{HbA}_{1} \mathrm{c}$, which was measured on the day of sample collection. Plasma glucose and serum total cholesterol and triacylglycerol concentrations were measured on a Cobas-Bio centrifugal analyser (Roche Diagnostica, Basel, Switzerland) using enzymatic kits (Hoffmann-La Roche Diagnostica, Basel, Switzerland) and control sera. Serum HDLcholesterol (HDL-C) concentrations were measured using a Cobas-Bio analyser after precipitation of lipoproteins containing apolipoprotein B with polyethylene glycol 6000 solution. A modified Friedewald equation was used to calculate LDLcholesterol (LDL-C) [13]. Insulin was determined in duplicate using a radioimmunoassay kit (Pharmacia \& Upjohn Diagnostics, Uppsala, Sweden). The homeostatic model assessment (HOMA) was used as a surrogate measure of insulin sensitivity based on fasting glucose and insulin concentrations [14], calculated as ([fasting serum insulin $\mathrm{x}$ fasting glucose]/22.5). CRP was measured using an enzymatic kit (Roche, Indianapolis, Ind., USA), on a Hitachi auto analyser (Roche, Indianapolis) and $\mathrm{HbA}_{1} \mathrm{c}$ samples were analysed by high-performance liquid chromatography [15]. Urinary urea, creatinine and albumin concentrations were measured in one run on a Hitachi auto analyser (Roche, Indianapolis) at the end of the study. If the urinary albumin concentration was lower than the detection level of $3.0 \mathrm{mg} / \mathrm{l}$, it was reported as $2 \mathrm{mg} / \mathrm{l}$. Urine albumin was expressed as an albumin : creatinine ratio (mg albumin/mmol creatinine).

Statistical analysis. Participants who failed to complete the entire 64-week study period were excluded from the final analysis and reported as dropouts. The final analysis was carried out on those subjects who remained in the study and attended the final clinic visit at Week 64 (low-protein diet: 19; high-protein diet: 19). Missing data for body weight at interim timepoints (i.e. Week 25, 38, 51) were replaced carrying the previous observation forward.

Baseline differences were compared using unpaired samples $t$ tests (two-tailed). Analysis of variance with repeated measures was used to determine the effects of the treatment, time of measurement, and their interactions on the dependent measures, with co-variate adjustments for baseline values and body weight using analysis of co-variance. The between-subject factors were the diet (i.e. high-protein or low-protein diet) and sex, with the time of measurement treated as within-subject factor. If significance was noted, Bonferroni adjusted $t$ tests were used to make post-hoc comparisons between and within groups. Since the primary objective was to determine changes during the follow-up after weight loss (i.e. Weeks 12 to 64), 95\% confidence intervals for the between-group differences in the within-group changes are presented for this time period. Relationships between changes in parameters over time were analysed using regression analysis. Statistical significance was defined as a $p$ value of less than 0.05. Data are presented as means \pm SEM. All statistical analyses were performed with SPSS for Windows 11.5.0 (SPSS, Chicago, Ill., USA).

\section{Results}

Body weight and composition. In both groups, the mean weight loss was $5.3 \mathrm{~kg}(5.7 \%$ loss of initial body weight) after the first 12 weeks (Table 2, Fig. 2). Although there was a significant weight regain during follow-up, body weight remained significantly lower at Week 64 than at baseline (low-protein diet: $-2.2 \pm$ $1.1 \mathrm{~kg}$; high-protein diet: $-3.7 \pm 1.0 \mathrm{~kg}$, time effect $p<0.01$ ), with no significant differential effect of sex or diet.

A significant reduction in lean body mass (LBM) and fat mass with weight loss was observed at the end of the 12-week intervention period (Table 2). Although fat mass after follow-up at Week 64 had increased to baseline levels, fat-free mass remained significantly lower than baseline. No effect of diet or sex was observed for changes in either tissue compartment. Bone mineral content was not different between diet groups at baseline and did not change during the study.

Blood pressure. Systolic blood pressure was slightly, but not significantly lower in the low-protein group than in the high-protein group at baseline (Table 3). Systolic blood pressure decreased by $6 \mathrm{~mm} \mathrm{Hg}$ during weight loss after 12 weeks with both diets, but there was no effect of diet composition ( $p=0.95)$. During the follow-up, systolic blood pressure increased by $8.1 \mathrm{~mm} \mathrm{Hg}$ more in the low-protein than in the highprotein group, with a significant time by diet interaction (low protein: $10.0 \pm 3.2 \mathrm{~mm} \mathrm{Hg}$; high protein: $1.9 \pm 1.9 \mathrm{~mm} \mathrm{Hg} ; p=0.04$ )

Diastolic blood pressure was significantly lower in the low-protein than in the high-protein group at baseline (Table 3). By Week 12, it had decreased by $3 \mathrm{~mm} \mathrm{Hg}$ with weight loss, but there was no effect of diet composition $(p=0.48)$. There was a significant time by diet interaction during follow-up, with diastolic blood pressure $5.7 \mathrm{~mm} \mathrm{Hg}$ higher in the lowprotein group than in the high-protein group (low-protein increase: $4.7 \pm 1.6 \mathrm{~mm} \mathrm{Hg}$; high protein: $-1.0 \pm$ $1.3 \mathrm{~mm} \mathrm{Hg} ; p=0.008$ ).

The time by diet interaction effects for both systolic and diastolic blood pressure were present after controlling for baseline differences. Results were also similar after adjustments for changes in weight.

Glycaemic control. Fasting glucose, insulin, HOMA and $\mathrm{HbA}_{1} \mathrm{c}$ concentrations were significantly reduced with energy restriction by Week 12 (Table 3), but in- 


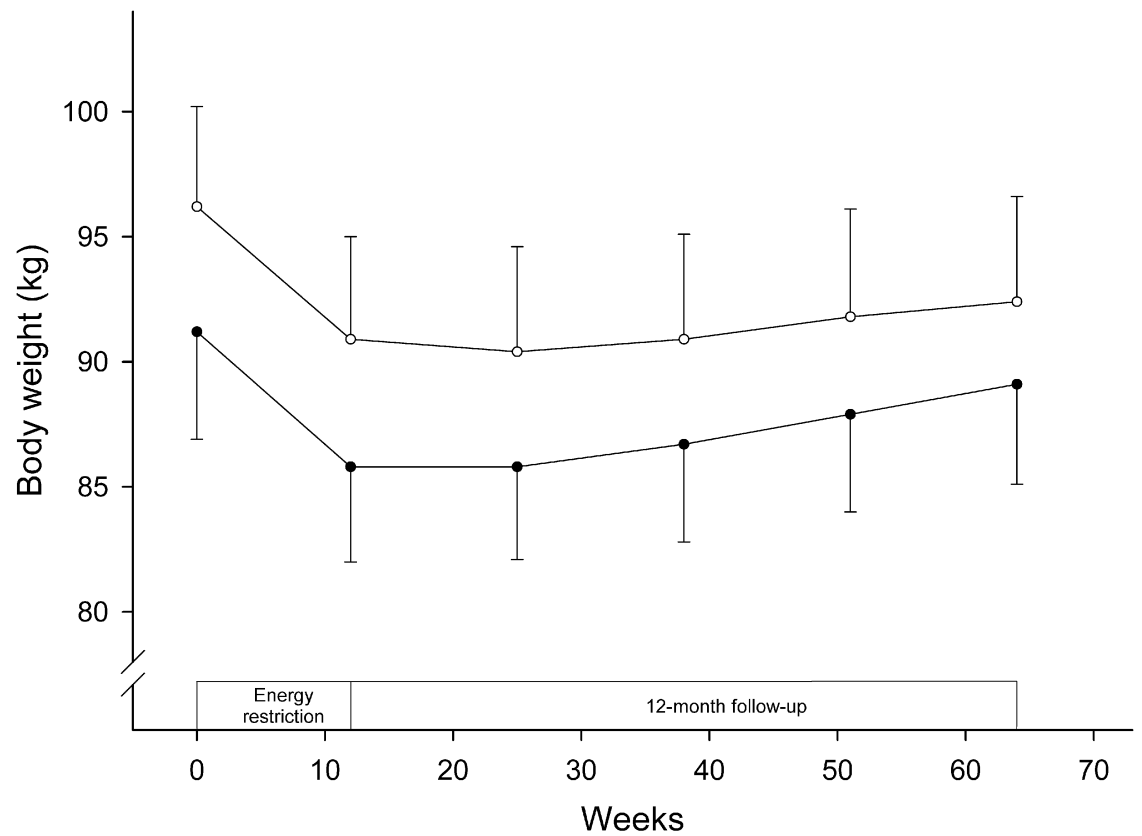

Fig. 2. Body weight during 8 weeks of energy restriction, 4 weeks of energy balance and 12 months of follow-up in subjects on a conventional low-protein diet and subjects on a highprotein diet. Filled circles, low-protein diet (LP) $(n=19)$; open circles, high-protein diet (HP) $(n=19)$. Values are means \pm
SEM. No time by diet interaction was observed. Not all subjects attended interim clinic visits at Week 25 (LP, $n=16$; HP, $n=18$ ), Week 38 (LP, $n=18$; HP, $n=14$ ) and Week 51 (LP, $n=17$; HP, $n=14)$. In the event of missing data for interim time points, values from the previous observation were carried forward

Table 2. Body weight and composition of subjects on a conventional low-protein $(n=19)$ or high-protein diet $(n=19)$

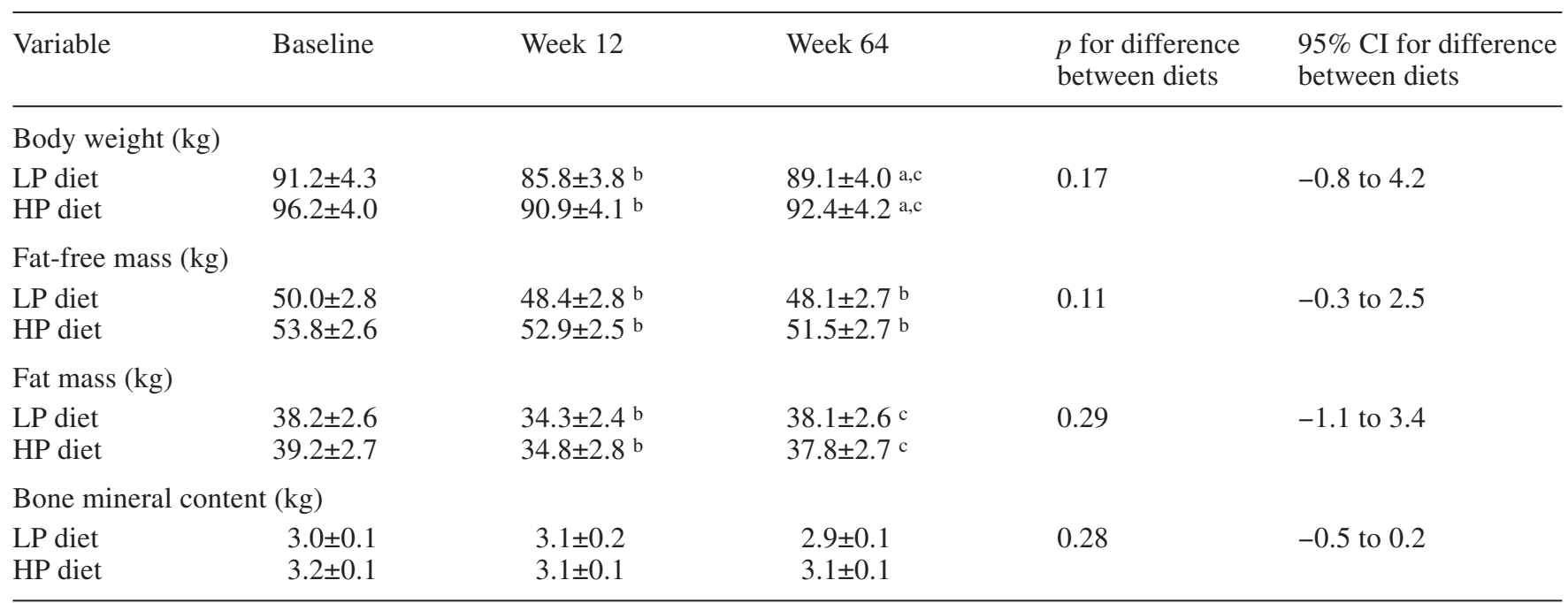

Values (means \pm SEM) are for the following time-points: baseline (prior to diet); Week 12 (after 8 weeks of energy restriction and 4 weeks of energy balance e); Week 64 (at 12-month follow-up after Week 12). LP, low protein; HP, high protein. The $p$ values represent treatment effect between groups for the

creased during the follow-up period such that no difference from baseline levels was detected at Week 64. No significant effect of diet or sex was observed for changes in any of these variables during the study.

C-Reactive protein. Overall, CRP decreased by $14 \%$ $(p=0.04)$ during the intervention, with no effect of dietary composition or sex (Table 3 ). change from Week 12 to 64 (repeated measures ANOVA). 95\% CIs are for difference in change between the two diet groups from Week 12 to 64 . a $p<0.01,{ }^{\mathrm{b}} p<0.001$ for difference from baseline; ${ }^{\mathrm{c}} p<0.05$ for difference from Week 12

Albumin. Microalbuminuria was defined as a urinary albumin : creatinine ratio of $\geq 2.5 \mathrm{mg} / \mathrm{mmol}$ [16]. At baseline, two subjects in the high-protein group had microalbuminuria of 3.21 and $2.54 \mathrm{mg} / \mathrm{mmol}$ respectively. The exclusion of these subjects from the analysis did not change the outcome, with no statistical difference in urinary albumin excretion between the groups and no change throughout the study (Table 3 ). 
Table 3. Laboratory values and blood pressure of subjects on a conventional low-protein $(n=19)$ or high-protein diet $(n=19)$

\begin{tabular}{|c|c|c|c|c|c|}
\hline Variable & Baseline & Week 12 & Week 64 & $\begin{array}{l}p \text { for difference } \\
\text { between diets }\end{array}$ & $\begin{array}{l}95 \% \text { CI for d } \\
\text { between diet }\end{array}$ \\
\hline \multicolumn{6}{|c|}{ Systolic blood pressure (mm Hg) } \\
\hline $\begin{array}{l}\text { LP diet } \\
\text { HP diet }\end{array}$ & $\begin{array}{l}139.9 \pm 3.4 \\
147.6 \pm 2.7\end{array}$ & $\begin{array}{l}133.6 \pm 3.0^{b} \\
141.1 \pm 2.7^{b}\end{array}$ & $\begin{array}{l}143.6 \pm 3.6^{\mathrm{d}} \\
143.0 \pm 2.6^{\mathrm{d}}\end{array}$ & 0.04 & 0.5 to 15.7 \\
\hline \multicolumn{6}{|c|}{ Diastolic blood pressure ( $\mathrm{mm} \mathrm{Hg}$ ) } \\
\hline $\begin{array}{l}\text { LP diet } \\
\text { HP diet }\end{array}$ & $\begin{array}{l}75.7 \pm 1.3^{*} \\
82.6 \pm 1.7\end{array}$ & $\begin{array}{l}73.5 \pm 2.1^{*}, \mathrm{a} \\
78.8 \pm 1.5{ }^{\mathrm{a}}\end{array}$ & $\begin{array}{l}78.2 \pm 1.7^{\mathrm{d}} \\
77.7 \pm 2.1^{\mathrm{a}}\end{array}$ & 0.008 & 1.6 to 9.8 \\
\hline \multicolumn{6}{|c|}{ Fasting glucose (mmol/l) } \\
\hline $\begin{array}{l}\text { LP diet } \\
\text { HP diet }\end{array}$ & $\begin{array}{l}7.5 \pm 0.3 \\
8.6 \pm 0.5\end{array}$ & $\begin{array}{l}6.9 \pm 0.3^{a} \\
8.0 \pm 0.4^{a}\end{array}$ & $\begin{array}{l}8.6 \pm 0.7 \mathrm{~d} \\
8.6 \pm 0.7 \mathrm{~d}\end{array}$ & 0.26 & -0.8 to 3.0 \\
\hline \multicolumn{6}{|c|}{ Fasting insulin (mU/l) } \\
\hline $\begin{array}{l}\text { LP diet } \\
\text { HP diet }\end{array}$ & $\begin{array}{l}15.7 \pm 1.8 \\
16.8 \pm 1.7\end{array}$ & $\begin{array}{l}13.5 \pm 1.7 \mathrm{~b} \\
14.2 \pm 1.7 \mathrm{~b}\end{array}$ & $\begin{array}{l}17.6 \pm 3.1 \mathrm{~d} \\
17.0 \pm 2.9^{\mathrm{d}}\end{array}$ & 0.63 & -4.5 to 7.3 \\
\hline \multicolumn{6}{|l|}{ HOMA } \\
\hline $\begin{array}{l}\text { LP diet } \\
\text { HP diet }\end{array}$ & $\begin{array}{l}5.4 \pm 0.9 \\
6.5 \pm 0.9\end{array}$ & $\begin{array}{l}4.2 \pm 0.5 \mathrm{~b} \\
5.1 \pm 0.7 \mathrm{~b}\end{array}$ & $\begin{array}{l}6.8 \pm 1.3 \mathrm{~d} \\
6.5 \pm 1.2 \mathrm{~d}\end{array}$ & 0.37 & -1.6 to 4.2 \\
\hline \multicolumn{6}{|l|}{$\mathrm{HbA}_{1} \mathrm{c}$} \\
\hline $\begin{array}{l}\text { LP diet } \\
\text { HP diet }\end{array}$ & $\begin{array}{l}6.2 \pm 0.2 \\
6.5 \pm 0.2\end{array}$ & $\begin{array}{l}5.7 \pm 0.1^{c} \\
6.0 \pm 0.2^{c}\end{array}$ & $\begin{array}{l}6.6 \pm 0.3 \mathrm{~d} \\
6.6 \pm 0.4 \mathrm{~d}\end{array}$ & 0.38 & -0.4 to 1.1 \\
\hline \multicolumn{6}{|c|}{ CRP (mg/l) } \\
\hline $\begin{array}{l}\text { LP diet } \\
\text { HP diet }\end{array}$ & $\begin{array}{l}4.2 \pm 0.7 \\
5.0 \pm 1.0\end{array}$ & $\begin{array}{l}4.1 \pm 0.9 \\
4.7 \pm 1.1\end{array}$ & $\begin{array}{l}3.6 \pm 0.7^{a} \\
3.8 \pm 0.8{ }^{a}\end{array}$ & 0.61 & -1.2 to 1.9 \\
\hline \multicolumn{6}{|c|}{ Urinary albumin : creatinine (mg/mmol) } \\
\hline $\begin{array}{l}\text { LP diet } \\
\text { HP diet }\end{array}$ & $\begin{array}{l}0.4 \pm 0.1 \\
0.6 \pm 0.1\end{array}$ & $\begin{array}{l}0.6 \pm 0.1 \\
0.5 \pm 0.1\end{array}$ & $\begin{array}{l}0.6 \pm 0.1 \\
0.5 \pm 0.1\end{array}$ & 0.91 & -0.3 to 0.2 \\
\hline
\end{tabular}

Values (means \pm SEM) are for the following time-points: baseline (prior to diet); Week 12 (after 8 weeks of energy restriction and 4 weeks of energy balance e); Week 64 (at 12-month follow-up after Week 12). LP, low protein; HP, high protein. The $p$ values represent treatment effect between groups for the

Blood lipids. Serum triacylglycerol, total cholesterol and the total cholesterol : HDL-C ratio fell significantly in both groups at Week 12, but increased during the follow-up, such that at Week 64 there were no significant differences compared to baseline (Table 4). The changes in these variables did not differ significantly between the treatment groups.

Fasting serum HDL-C did not change during energy restriction, but a main effect of time was that levels had increased by $17 \%(0.16 \pm 0.02 \mathrm{mmol} / \mathrm{l})$ in both diet groups by Week 64; this was not affected by either diet or sex. The change in HDL-C was not correlated with changes in body weight $(r=-0.03, p=0.88)$ and fat mass $(r=0.07, p=0.66)$. The fluctuations in serum LDL-C did not differ between the treatment groups (8\% higher in the low-protein group vs $-6 \%$ in the high-protein group) (Table 4).

Dietary compliance and composition. The urinary urea : creatinine ratio was not different between the two dietary groups at Week 0 (low protein: $35.6 \pm 1.7$; change from Weeks 12 to 64 (repeated measures ANOVA). 95\% CIs are for difference in change between the two diet groups from Weeks 12 to $64 .{ }^{*} p<0.05$ for lower compared to HP; ${ }^{\mathrm{a}} p<0.05,{ }^{\mathrm{b}} p<0.01,{ }^{\mathrm{c}} p<0.001$ for difference from baseline; d $p<0.05$ for difference from Week 12

high protein $33.7 \pm 1.6 ; p=0.42$ ). A significant time by diet effect was observed during the study period $(p=0.004)$, whereby urinary urea : creatinine increased by $27.4 \pm 6.1 \%$ from baseline at Week 12 in the highprotein group, but did not change in the low-protein group. During the next 12 months, urinary urea : creatinine remained stable in both groups, leaving urinary urea : creatinine at Week 64 significantly higher than baseline in the high-protein group $(p=0.01)$, with no difference to baseline in the low-protein group $(p=0.78)$. These results indicate that compliance with the protein prescription in the two diet groups was good.

Power calculations. Retrospective power calculations for the follow-up period indicated that the sample size was sufficient to detect a significant difference in weight regain of $4.5 \mathrm{~kg}$ between the diet groups with $88 \%$ power and a $p$ value of 0.05 . The effect of diet composition showed non-statistically significant effects for LDL and triacylglycerol. In order for the ob- 
Table 4. Blood lipids of subjects on a conventional low-protein $(n=19)$ or high-protein diet $(n=19)$

\begin{tabular}{|c|c|c|c|c|c|}
\hline Variable & Baseline & Week 12 & Week 64 & $\begin{array}{l}p \text { value for difference } \\
\text { between diets }\end{array}$ & $\begin{array}{l}95 \% \text { CI for difference } \\
\text { between diets }\end{array}$ \\
\hline \multicolumn{6}{|c|}{ Total cholesterol (mmol/l) } \\
\hline $\begin{array}{l}\text { LP diet } \\
\text { HP diet }\end{array}$ & $\begin{array}{l}5.17 \pm 0.21 \\
5.17 \pm 0.20\end{array}$ & $\begin{array}{l}5.07 \pm 0.22^{\mathrm{a}} \\
4.80 \pm 0.20^{\mathrm{a}}\end{array}$ & $\begin{array}{l}5.52 \pm 0.27 \mathrm{~d} \\
5.25 \pm 0.25 \mathrm{~d}\end{array}$ & 0.99 & -0.6 to 0.6 \\
\hline \multicolumn{6}{|c|}{ LDL-C (mmol/l) } \\
\hline \multicolumn{6}{|c|}{ HDL-C (mmol/l) } \\
\hline $\begin{array}{l}\text { LP diet } \\
\text { HP diet }\end{array}$ & $\begin{array}{l}0.95 \pm 0.06 \\
0.93 \pm 0.05\end{array}$ & $\begin{array}{l}0.98 \pm 0.04 \\
0.91 \pm 0.05\end{array}$ & $\begin{array}{l}1.10 \pm 0.06^{\mathrm{c}, \mathrm{d}} \\
1.09 \pm 0.06^{\mathrm{c}, \mathrm{d}}\end{array}$ & 0.23 & -0.17 to 0.04 \\
\hline \multicolumn{6}{|c|}{ Total cholesterol : HDL-C } \\
\hline
\end{tabular}

Values (means \pm SEM) are for the following time-points: baseline (prior to diet); Week 12 (after 8 weeks of energy restriction and 4 weeks of energy balance e); Week 64 (at 12-month follow-up after Week 12). LDL-C, LDL cholesterol; HDL-C, HDL cholesterol; LP, low protein; HP, high protein. The $p$ val-

served differences in the change in LDL and triacylglycerol levels between the two groups to be significant with $80 \%$ power and a $p$ value of less than 0.05 (two-tailed), 87 and 52 subjects respectively would be required in each group. For the current sample size, the differences between the experimental groups for the changes in systolic and diastolic blood pressure during the follow-up had $82 \%$ and $88 \%$ power respectively to be significant with a type 1 error of 5\% (twotailed).

\section{Discussion}

After initial weight loss, advice to consume a low-fat diet that was higher in protein and lower in carbohydrate attenuated increases in blood pressure with weight regain during 12-months of follow-up compared to a conventional high-carbohydrate, low-fat diet in obese subjects with Type 2 diabetes. However, there was no difference in overall weight loss between diets.

The amount of weight lost after the initial energy restriction period was comparable to previous studies over 10 to 12 weeks in patients with Type 2 diabetes $[17,18]$. Consistent with other studies, both groups regained weight during follow-up, but maintained a net weight loss at Week $64[6,19]$. While the highprotein diet produced a $1.7 \mathrm{~kg}$ (non-significant) smaller weight regain than the low-protein one, we only had sufficient power to detect a $4.2 \mathrm{~kg}(\sim 5 \%$ body ues represent treatment effect between groups for the change from Weeks 12 to 64 (repeated measures ANOVA). 95\% CIs are for difference in change between the two diet groups from Weeks 12 to 64 . ${ }^{\mathrm{a}} p<0.05 ;{ }^{\mathrm{b}} p<0.01 ;{ }^{\mathrm{c}} p<0.001$ for difference from baseline; ${ }^{\mathrm{d}} p<0.05$ for increase against Week 12

weight) difference in weight regain between diets. This could be considered the minimum level for biological significance, since weight loss of $5 \%$ or more reduces co-morbidity and mortality risk in obese subjects [20]. Weight loss was due principally to changes in LBM, with minimal contribution of fat loss and no differential effect of diet. These data suggest that a higher protein intake offers no greater advantages in maintaining long-term weight loss or improving body composition than does a conventional high-carbohydrate diet in obese patients with Type 2 diabetes over 12 months.

In contrast to our results and others [17], similar trials performed in non-diabetic, obese individuals have reported long-term weight loss principally due to reductions in fat mass $[21,22]$. This preferential loss of LBM in Type 2 diabetes may be due to a higher whole-body proteolytic rate associated with moderate hyperglycaemia [23]. Our results suggest this effect may occur independently of protein intake although a higher protein intake has previously been shown to suppress proteolysis of lean tissue in obese healthy adults [24]. Loss of LBM may pose problems for maintenance of long-term weight loss [25] and glycaemic control [26]. Hence, treatment of obesity in patients with diabetes should aim to preserve lean body mass during weight reduction, which could be achieved by an accompanying exercise programme [26]. Future long-term follow-up studies should examine the combined effects of physical activity and these dietary patterns as strategies for weight management. 
We found no significant difference in glycaemic control between subjects on the two diets. In contrast, a small study of 12 obese subjects with Type 2 diabetes showed a small, but significant improvement in $\mathrm{HbA}_{1} \mathrm{c}$ over 5 weeks on a weight-maintaining highprotein diet containing a protein : carbohydrate : fat ratio of 30:40:30, compared to an isocaloric low-protein diet (15:55:30) [10]. Since LBM is associated with glycaemic control [26], it is possible that the loss of LBM in our subjects may have masked any small effect of diet on glucose control. However, subjects in our study were initially well controlled $\left(\mathrm{HbA}_{1} \mathrm{c} 6.4 \%\right)$ compared to subjects at the start of the previous study $\left(\mathrm{HbA}_{1} \mathrm{c} 8 \%\right)$, which would have been the major determinant of improvement in $\mathrm{HbA}_{1} \mathrm{c}$.

Rebound increases in blood pressure with weight regain were attenuated in the high-protein group, such that systolic blood pressure and diastolic blood pressure increased to a greater extent in the low-protein group than in the high-protein group, on average by 8.1 and $5.7 \mathrm{~mm} \mathrm{Hg}$ respectively. This improvement has a significant effect on lowering the risk of cardiovascular events and complications [27, 28]. Given the high power observed for these diet effects on blood pressure, the possibility of a type 1 error is low; however, the precise mechanism could not be determined from the present data. Initial blood pressure levels were somewhat higher in the high-protein group, but analysis of co-variance showed this was not the reason for the smaller blood pressure increases in that group during follow-up. Based on our analysis and previous data [29], the small differences in weight regain between the diets would also fail to explain the differential blood pressure changes observed. It is therefore likely that the higher protein intake in the high-protein diet was responsible for the attenuated rise in blood pressure. Observations from several large epidemiological studies [30, 31] and short-term (6-13 week) clinical trials $[32,33]$ have demonstrated that protein intake may be inversely related to blood pressure, although which component of dietary protein might be involved is unclear. The present data also support the hypothesis that a long-term higher protein intake may help to lower blood pressure and CVD risk in people with diabetes.

After 15 months, both groups showed increases in HDL-C (17\%) irrespective of the regain in weight and fat mass during follow-up. Other studies have reported comparable results in healthy obese [34] hyperinsulinaemic subjects [35] or people with Type 2 diabetes [17]. In particular the latter study showed increases in HDL-C despite no net loss of fat at 18 months. The increases in HDL-C are greater than those expected from moderate weight loss alone [36], suggesting that factors other than weight loss are important. However, because these improvements were not supported by changes in other metabolic parameters, such as triglyceride, we have found it difficult to explain them. It is possible there is a time delay between an increase in weight and a subsequent fall in HDL-C. Nonetheless, a $1 \%$ increase in HDL-C may constitute a $3 \%$ reduction in heart disease risk [37], and therefore the relatively large increases observed in our subjects could translate into a substantial reduction in CVD risk.

In contrast with previous findings [12], we did not observe a significant reduction in LDL-C in the highprotein group. However, the study was not sufficiently powered to determine a diet effect. Thus the long-term effects of high-protein diets on LDL-C in Type 2 diabetes remain to be determined.

CRP is an inflammatory molecule directly implicated in the atherosclerotic process and has been identified as an independent predictor of future cardiac events [38]. In this study, CRP levels improved in both groups over the study period by amounts that have a clinically significant benefit [39], despite regain of all the fat lost in the initial intervention. Thus the CRP and HDL-C changes mirror each other and may represent better overall health status in the volunteers.

Consumption of high-protein diets has been associated with potentially adverse effects, notably the development of diabetic nephropathy [40]. In the present study there were no changes in urinary albumin excretion in either group. Cross-sectional [41] and clinical studies [42] in people with diabetes have not shown an association between protein intake and albumin excretion nor a beneficial effect of chronic protein restriction on the course of albuminuria or on prevention/delaying of renal damage. Similarly, Skov and co-workers [43] found no changes in urinary albumin excretion between obese, healthy subjects consuming as much as they wanted of either a low-fat, high-protein or low-protein diet ( $25 \%$ vs $12 \%$ of energy as protein) over 6 months, and that changes in urinary albumin excretion were inversely correlated with dietary protein intake. These data suggest that habitual high protein intake constituting up to $30 \%$ of dietary energy is unlikely to have detrimental effects on progression of microalbuminuria in Type 2 diabetes patients with no clinically obvious renal dysfunction. However, further studies should examine the longterm dose-response effects of higher levels of dietary protein intake in persons with renal disease.

A limitation of the present study was the lack of dietary data. Although urinary urea : creatinine excretion provided an effective biomarker of protein intake, it was not possible to determine dietary changes of other nutrient components (e.g. dietary fatty acids) that may have exerted metabolic effects on the parameters investigated such as blood lipid levels. Consequently, it is difficult to interpret some of the longterm effects that we observed and that may be related to dietary components other than protein. Furthermore, the relatively high dropout rate and the consequent reduced study power may have reduced the sensitivity of the results. A larger study, with greater em- 
phasis on subject compliance to dietary assessment tools would assist in elucidating the long-term effects of these dietary patterns.

In summary, neither diet achieved long-term net fat loss, but prescription of the high-protein diet had a more favourable effect on CVD risk by lowering blood pressure to a greater extent than a conventional low-protein diet in overweight patients with Type 2 diabetes. Further research is needed to substantiate these results and to gain a greater understanding of the net cardiovascular effects of these dietary patterns. In addition, it is important to differentiate between highprotein, low-fat diet plans and other variants such as high-protein, high-fat, very-low-carbohydrate diet plans, because adherence to these diets has been associated with adverse metabolic effects [44].

Acknowledgements. This study was supported in part by Meadow Lea Foods, Mascot, NSW, Australia . We thank Kay Pender, Anne McGuffin, and Rosemary McArthur for their assistance in conducting this study.

\section{References}

1. Zimmet P, Alberti KG, Shaw J (2001) Global and societal implications of the diabetes epidemic. Nature 414:782-787

2. Marks JB, Raskin P (2000) Cardiovascular risk in diabetes: a brief review. J Diabetes Complications 14:108-115

3. Haffner SM (1998) Epidemiology of type 2 diabetes: risk factors. Diabetes Care 21 [Suppl 3]:C3-C6

4. The Diabetes and Nutrition Group (DNSG) of the European Association for the Study of Diabetes (2000) Recommendations for the nutritional management of patients with diabetes mellitus. Eur J Clin Nutr 54:353-355

5. American Diabetes Association (2002) American Diabetes Association position statement: evidence-based nutrition principles and recommendations for the treatment and prevention of diabetes and related complications. J Am Diet Assoc 102:109-118

6. Hensrud DD (2001) Dietary treatment and long-term weight loss and maintenance in type 2 diabetes. Obes Res 9 [Suppl 4]:348S-353S

7. Skov AR, Toubro S, Ronn B, Holm L, Astrup A (1999) Randomized trial on protein vs carbohydrate in ad libitum fat reduced diet for the treatment of obesity. Int J Obes Relat Metab Disord 23:528-536

8. Layman DK, Boileau RA, Erickson DJ et al. (2003) A reduced ratio of dietary carbohydrate to protein improves body composition and blood lipid profiles during weight loss in adult women. J Nutr 133:411-417

9. Parker B, Noakes M, Luscombe N, Clifton P (2002) Effect of a high-protein, high-monounsaturated fat weight loss diet on glycemic control and lipid levels in type 2 diabetes. Diabetes Care 25:425-430

10. Gannon MC, Nuttall FQ, Saeed A, Jordan K, Hoover H (2003) An increase in dietary protein improves the blood glucose response in persons with type 2 diabetes. Am J Clin Nutr 78:734-741

11. Farnsworth E, Luscombe ND, Noakes M, Wittert G, Argyiou E, Clifton PM (2003) Effect of a high-protein, energy-restricted diet on body composition, glycemic control, and lipid concentrations in overweight and obese hyperinsulinemic men and women. Am J Clin Nutr 78:31-39
12. Wolfe BM, Piche LA (1999) Replacement of carbohydrate by protein in a conventional-fat diet reduces cholesterol and triglyceride concentrations in healthy normolipidemic subjects. Clin Invest Med 22:140-148

13. Friedewald WT, Levy RI, Fredrickson DS (1972) Estimation of the concentration of low-density lipoprotein cholesterol in plasma, without use of the preparative ultracentrifuge. Clin Chem 18:499-502

14. Matthews DR, Hosker JP, Rudenski AS, Naylor BA, Treacher DF, Turner RC (1985) Homeostasis model assessment: insulin resistance and beta-cell function from fasting plasma glucose and insulin concentrations in man. Diabetologia 28:412-419

15. Jeppsson JO, Jerntorp P, Sundkvist G, Englund H, Nylund V (1986) Measurement of hemoglobin A1c by a new liquid-chromatographic assay: methodology, clinical utility, and relation to glucose tolerance evaluated. Clin Chem 32:1867-1872

16. Mogensen CE, Keane WF, Bennett PH et al. (1995) Prevention of diabetic renal disease with special reference to microalbuminuria. Lancet 346:1080-1084

17. Ash S, Reeves MM, Yeo S, Morrison G, Carey D, Capra S (2003) Effect of intensive dietetic interventions on weight and glycaemic control in overweight men with Type II diabetes: a randomised trial. Int J Obes 27:797-802

18. Heilbronn LK, Noakes M, Clifton PM (1999) Effect of energy restriction, weight loss, and diet composition on plasma lipids and glucose in patients with type 2 diabetes. Diabetes Care 22:889-895

19. Anderson JW, Konz EC, Frederich RC, Wood CL (2001) Long-term weight-loss maintenance: a meta-analysis of US studies. Am J Clin Nutr 74:579-584

20. Van Gaal LF, Wauters MA, De Leeuw IH (1997) The beneficial effects of modest weight loss on cardiovascular risk factors. Int J Obes Relat Metab Disord 21 [Suppl 1]:S5-S9

21. Toubro S, Astrup A (1997) Randomised comparison of diets for maintaining obese subjects' weight after major weight loss: ad lib, low fat, high carbohydrate diet $\mathrm{v}$ fixed energy intake. BMJ 314:29-34

22. Westerterp-Plantenga MS, Kempen KP, Saris WH (1998) Determinants of weight maintenance in women after dietinduced weight reduction. Int J Obes Relat Metab Disord 22:1-6

23. Gougeon R, Styhler K, Morais JA, Jones PJ, Marliss EB (2000) Effects of oral hypoglycemic agents and diet on protein metabolism in type 2 diabetes. Diabetes Care 23:1-8

24. Piatti PM, Monti F, Fermo I et al. (1994) Hypocaloric highprotein diet improves glucose oxidation and spares lean body mass: comparison to hypocaloric high-carbohydrate diet. Metabolism 43:1481-1487

25. Pasman WJ, Saris WH, Muls E, Vansant G, WesterterpPlantenga MS (1999) Effect of exercise training on longterm weight maintenance in weight-reduced men. Metabolism 48:15-21

26. Castaneda C, Layne JE, Munoz-Orians L et al. (2002) A randomized controlled trial of resistance exercise training to improve glycemic control in older adults with type 2 diabetes. Diabetes Care 25:2335-2341

27. Appel LJ, Moore TJ, Obarzanek E et al. (1997) A clinical trial of the effects of dietary patterns on blood pressure. DASH Collaborative Research Group. N Engl J Med 336:1117-1124

28. Heart Outcomes Prevention Evaluation Study Investigators (2000) Effects of ramipril on cardiovascular and microvascular outcomes in people with diabetes mellitus: results of the HOPE study and MICRO-HOPE substudy. Heart Outcomes Prevention Evaluation Study Investigators. Lancet 355:253-259 
29. MacMahon S, Cutler J, Brittain E, Higgins M (1987) Obesity and hypertension: epidemiological and clinical issues. Eur Heart J 8 [Suppl B]:57-70

30. Appel LJ (2003) The effects of protein intake on blood pressure and cardiovascular disease. Curr Opin Lipidol 14:55-59

31. Liu L, Ikeda K, Sullivan DH, Ling W, Yamori Y (2002) Epidemiological evidence of the association between dietary protein intake and blood pressure: a meta-analysis of published data. Hypertens Res 25:689-695

32. Teede HJ, Dalais FS, Kotsopoulos D, Liang YL, Davis S, McGrath BP (2001) Dietary soy has both beneficial and potentially adverse cardiovascular effects: a placebo-controlled study in men and postmenopausal women. J Clin Endocrinol Metab 86:3053-3060

33. Burke V, Hodgson JM, Beilin LJ, Giangiulioi N, Rogers P, Puddey IB (2001) Dietary protein and soluble fiber reduce ambulatory blood pressure in treated hypertensives. Hypertension 38:821-826

34. Lovejoy JC, Bray GA, Lefevre M et al. (2003) Consumption of a controlled low-fat diet containing olestra for 9 months improves health risk factors in conjunction with weight loss in obese men: the Ole' Study. Int J Obes Relat Metab Disord 27:1242-1249

35. Brinkworth GD, Noakes M, Keogh JB, Luscombe ND, Wittert GA, Clifton PM (2004) Long-term effects of a high-protein, low-carbohydrate diet on weight control and cardiovascular risk markers in obese hyperinsulinemic subjects. Int J Obes Relat Metab Disord 28:661-670

36. Dattilo AM, Kris-Etherton PM (1992) Effects of weight reduction on blood lipids and lipoproteins: a meta-analysis. Am J Clin Nutr 56:320-328
37. Boden WE (2000) High-density lipoprotein cholesterol as an independent risk factor in cardiovascular disease: assessing the data from Framingham to the Veterans Affairs High-Density Lipoprotein Intervention Trial. Am J Cardiol 86:19L-22L

38. Blake GJ, Ridker PM (2002) Inflammatory bio-markers and cardiovascular risk prediction. J Intern Med 252:283294

39. Ridker PM, Rifai N, Clearfield M et al. (2001) Measurement of C-reactive protein for the targeting of statin therapy in the primary prevention of acute coronary events. N Engl J Med 344:1959-1965

40. Pijls LT, Vries H de, Donker AJ, Eijk JT van (1999) The effect of protein restriction on albuminuria in patients with type 2 diabetes mellitus: a randomized trial. Nephrol Dial Transplant 14:1445-1453

41. Jameel N, Pugh JA, Mitchell BD, Stern MP (1992) Dietary protein intake is not correlated with clinical proteinuria in NIDDM. Diabetes Care 15:178-183

42. Pijls LT, Vries H de, Eijk JT van, Donker AJ (2002) Protein restriction, glomerular filtration rate and albuminuria in patients with type 2 diabetes mellitus: a randomized trial. Eur J Clin Nutr 56:1200-1207

43. Skov AR, Toubro S, Bulow J, Krabbe K, Parving HH, Astrup A (1999) Changes in renal function during weight loss induced by high vs low-protein low-fat diets in overweight subjects. Int J Obes Relat Metab Disord 23:11701177

44. Foster GD, Wyatt HR, Hill JO et al. (2003) A randomized trial of a low-carbohydrate diet for obesity. N Engl J Med 348:2082-2090 